\title{
DEVELOPMENT AND STANDARDIZATION OF A SIMPLE TECHINIQUE FOR BREAKING SEED DORMANCY IN SUNFLOWER (Helianthus annuus L.)
}

Maiti, R.K. ${ }^{1^{*}}$, Vidyasagar, P. $^{1}$, Shahapur, S.C. $^{1}$, Ghosh, S.K. ${ }^{1}$ and Seiler, G.J. ${ }^{2}$

${ }^{1}$ Vibha Agrotech Ltd., 501, Sirisampada, Rajbhavan Road, Samajiguda, Hyderabad- 500 082, A.P., India

${ }^{2}$ USDA-ARS, Northern Crop Science Laboratory, Fargo, ND 58105, USA

Received: October 15, 2006 Accepted: December 05, 2006

SUMMARY

\begin{abstract}
Seed dormancy causes a great problem in efficient seed production of sunflower. Attempts have been made to develop simple techniques for breaking seed dormancy. In the first experiment, different techniques were evaluated using treatments such as a growth regulator, Ethrel, priming (water soaking followed by 2-3 days drying in shade), chemicals such as acetone $\left(\mathrm{CH}_{3} \mathrm{COCH}_{3}\right)$, and potassium nitrate $\left(\mathrm{KNO}_{3}\right)$ which showed the most promise. To confirm these findings, several treatments $\left(25 \%\right.$ acetone, $0.2 \% \mathrm{KNO}_{3}$ and $24 \mathrm{~h}$ water soaking followed by drying) were further evaluated on 12 sunflower genotypes. Priming for $24 \mathrm{~h}$ in water is considered a simple and promising technique to break seed dormancy. This needs to be further confirmed using sunflower genotypes with different maturity groups and also with different periods of soaking in future experiments.
\end{abstract}

Key words: sunflower, Helianthus annuus, dormancy, simple technique, genotypic variability

\section{INTRODUCTION}

Sunflower is an important crop for the production of healthy edible oil that can help to reduce cardiac problems thereby increasing the demand for its oil. Therefore, there is a need to increase seed production of sunflower. Several factors such as temperature, water stress and depth of sowing greatly affect seedling emergence and seedling vigor of sunflower. The irregular shape and small seed size are other factors affecting seedling emergence (Connor and Hall, 1997). The presence of dormancy can cause great germination problems in sunflower seed. Dormancy is a temporary suspension of growth and development, which is endogenously control-

* Corresponding author: Phone: 91-40-23088078, Fax: 91-40-2332 4483,

e-mail: rkmaiti@yahoo.com 
led, but also environmentally imposed (Amen, 1968). It generally takes more than 30 to 40 days after harvest for sunflower seed to attain germination capacity, thereby, delaying the immediate sowing of the crop causing a problem in its commercialization. Producers of planting seed have to manipulate the date of sowing so that they have enough time to break dormancy naturally. In one study, it was shown that seeds removed from a head 10 to 12 days after fertilization and immediately sown in moist soil have the capacity to germinate. This technique permits the sowing of the crop at several different times in a single year (Martin, 2000).

Sunflower seed attain germination capacity about 6 days after pollination and becomes dormant 16 days after pollination. Ahmed (2002) studied the effect of the age of developing kernel on germination and dormancy in a sunflower hybrid. The germination percentage obtained 40 days after anthesis (DAA) was highest (97\%), followed by 34 DAA (92\%), and 36DAA (86\%).

The dormancy mechanism is not well known. The accumulation of abscisic acid (ABA) during maturity is considered to be involved in dormancy (Le Page-Degivry and Garello, 1991). Pericarp and seed coat thickness also contribute to dormancy. Genotypic variability in seed dormancy has been reported by Subrahmanyam et al. (2002). The presence of secondary dormancy and its variations among sunflower cultivars also should also be taken in account (Holec et al., 2002).

Several growth regulators and chemical treatments are used to break dormancy and enhance sunflower germination. Ethylene and its precursors enhance the breaking of dormancy (Corbineau et al., 1990). The synthesis of ethylene and its use in sunflower seed dormancy regulation have been discussed by Corbineau et al. (1990), Corbineau and Cóme (2003). In this respect, Kumari and Singh (2000) demonstrated that ethepon at a dose of $250 \mathrm{ppm}$ enhanced seed germination. At present, Ethrel is used commercially to break seed dormancy in sunflower. It has been suggested that protease activity may be involved in the removal of dormancy by ethylene and the improvement of germination of the sunflower embryo (Borghetti et al., 2002).

Several researchers have attempted to develop techniques to break seed dormancy but with little success. Several organic compounds such as acetone, chloroform, ethanol and many other compounds which have lipophilic properties, some degree of polarity and low molecular weight have the capacity to break seed dormancy (Adkins et al., 1984; Cohn et al., 1989; Corbineau et al., 1991). Taylorson and Hendricks (1979) reported that ethanol breaks seed dormancy in weedy grasses. It has been stated that prolonged exposure of sunflower achene membranes to ethanol may change the cell membrane permeability leading to permanent change, not affected by hydration and dehydration. Similarly, priming in the $\mathrm{KNO}_{3}$ solutions significantly improves germination of some crop species such as muskmelon (Nerson and Govers, 1986) and watermelon (Sachs, 1977). A 5mM $\mathrm{KNO}_{3}$ solution doubled the germination rate of cultivated sunflower indicating that $\mathrm{KNO}_{3}$ may influence the formation of free radicals, which in turn improve vigor 
(Singh and Rao, 1993). Seiler (1993) reported that the age of achenes at harvest of wild Helianthus annuus and $H$. petiolaris had a significant influence on germination; the majority of germination took place by 21 days. A combination of storage temperatures and time could not break dormancy. Akinola et al. (2000) used different seed treatments to induce germination in wild sunflower indicating that hot water at $80^{\circ} \mathrm{C}$ is effective for breaking dormancy.

In the case of wild species of sunflower, Seiler (1994) reported that chemical pre-treatment (priming) of wild sunflower achenes with a $1 \mathrm{mM}$ solution of gibberellic acid $\left(\mathrm{GA}_{3}\right)$ almost doubled germination percentage over a non-treated control. In a subsequent study, Seiler (1998) reported that the seeds of $H$. petiolaris treated with $\mathrm{GA}_{3}$ enhanced germination to $60 \%$ irrespective of maturity and storage time compared with $30 \%$ in the control. It was observed that achenes harvested 20 days after flowering had greater germination than those harvested 40 days after flowering.

In the light of the reviewed literature, it was concluded that very little success has been achieved in developing a simple, efficient and inexpensive technique for breaking seed dormancy of sunflower seeds. Although the use of Ethrel is promising, it is too costly. The objective of the present paper was to select an efficient, simple, and inexpensive standardized technique for breaking seed dormancy in sunflower.

\section{MATERIALS AND METHODS}

Two experiments were conducted to select a simple, efficient, standardized, and inexpensive technique to break seed dormancy. In order to attain this objective, we used seeds of a recently harvested non-dormant sunflower genotype in the first experiment. In all experiments, standard germination tests in Petri plates, using 50 seeds per plate, were replicated four times. In order to avoid disease infestation in all the experiments, seeds were treated with a $10 \%$ sodium hypochlorite for 10 minutes, rinsed, and then were the various treatments applied.

\section{Experiment 1}

Fifty seeds of a non-dormant sunflower (VBSG-230077) recently harvested were soaked in various chemical solutions as pre-germination treatments. The treatments included: 1) control (no treatment); 2) boiling water at $100^{\circ} \mathrm{C}$ for 15 min; 3) boiling water at $100^{\circ} \mathrm{C}$ for $15 \mathrm{~min}$, plus 1 day drying at room temperature; 4) hot water at $80^{\circ} \mathrm{C}$ for $15 \mathrm{~min}$, plus 1 day drying at room temperature; 5) Ethrel soaking for 1 day in $0.3 \mathrm{ml} / 1$; 6) Ethrel soaking for 1 day in $0.4 \mathrm{ml} / 1$; 7) water soaking for $5 \mathrm{~h}$ plus 2 days drying; 8) water soaking $12 \mathrm{~h}$ plus 2 days drying in shade; 9) water soaking $24 \mathrm{~h}$ plus drying at room temperature for 7 days; 10) water soaking $34 \mathrm{~h}$ plus drying for 7 days at room temperature; 11) acetone $\left(\mathrm{CH}_{3} \mathrm{COCH}_{3}\right)(25 \%)$ for 15 minute, then rinsed; 12$)$ potassium nitrate $\left(0.2 \% \mathrm{KNO}_{3}\right)$ for 10 minutes. 
After treatment, seeds were placed between two pieces of germination paper $9 \mathrm{~cm}$ in diameter in Petri dishes saturated with $15 \mathrm{ml}$ of distilled water and placed at room temperature $\left(25-30^{\circ} \mathrm{C}\right)$. All treatments were replicated four times. The number of seeds germinated was counted 4 and 7 days after treatment. A seed was considered germinated when the radicle reached a length of about $5 \mathrm{~mm}$.

\section{Experiment 2}

Based on the results from the first experiment, promising treatments were further evaluated using 12 recently harvested sunflower genotypes belonging to different maturity groups based on the number of days to $50 \%$ flowering (Table 1 ).

Table 1: Twelve sunflower genotypes with different days to $50 \%$ flowering used to evaluate different techniques to enhance germination

\begin{tabular}{lcc}
\hline No. & Genotype & Days to 50\% flowering \\
\hline 1 & VBSG-210019 & 62 \\
2 & VBSG-230057 & 59 \\
3 & VBSG-210022 (Source-1) & 68 \\
4 & VBSG-230077 & 60 \\
5 & VBSG-230044 & 59 \\
6 & VBSG-230021 & 73 \\
7 & VBSG-230012 & 60 \\
8 & VBSG-210022 (Source-2) & 68 \\
9 & VBSG-230064 & 59 \\
10 & VBSG-230065 & 62 \\
11 & VBSG-210002 & 58 \\
12 & VBSG-230029 & 56 \\
\hline
\end{tabular}

Fifty seeds of each genotype were germinated in $9 \mathrm{~cm}$ diameter Petri dishes between two pieces of germination paper saturated with $15 \mathrm{ml}$ of distilled water. The treatments were replicated four times. Petri dishes were kept at room temperature of $25-30^{\circ} \mathrm{C}$ in the laboratory. Four treatments were tested; 1 ) control (distilled water); 2) acetone $25 \%$ for $15 \mathrm{~min}$; 3) $0.2 \mathrm{ml} / 1 \mathrm{KNO}_{3}$ for $15 \mathrm{~min}$; and 4) priming (24 $\mathrm{h}$ soaking followed by drying for 3 days at room temperature). Germination counts were taken 7 days after treatment. Statistical analysis was preformed on the total number of seeds germinated in the period of 7 days. The statistical design used was a randomized complete block design with four replications.

\section{RESULTS AND DISCUSSION}

\section{Experiment 1}

Germination percentages of seed of a dormant sunflower hybrid using different techniques to break dormancy in sunflower are given in Table 2. An analysis of var- 
iance of seed treatments four and seven days after the beginning of the experiment is given in Table 3.

Table 2: Different techniques evaluated for breaking dormancy in seed of sunflower genotypes

\begin{tabular}{llcc}
\hline \multirow{2}{*}{ No. } & \multirow{2}{*}{ Treatment } & $4^{\text {th }}$ day & $7^{\text {th }}$ day \\
\cline { 3 - 4 } & & \multicolumn{2}{c}{ Germination $\%$} \\
\hline 1 & Control (no treatment) & 96.5 & 99 \\
2 & Hot water $100^{\circ} \mathrm{C}$ for $15 \mathrm{~min}$ & 42 & 83 \\
3 & Hot water $100^{\circ} \mathrm{C}$ for $15 \mathrm{~min}+1$ day drying $20^{\circ} \mathrm{C}$ & 72.5 & 96 \\
4 & Warm water $80^{\circ} \mathrm{C}$ for $15 \mathrm{~min}+1$ day drying $20^{\circ} \mathrm{C}$ & 86.5 & 92.5 \\
5 & Ethrel soaking 1 day in $0.3 \mathrm{ml} / \mathrm{l}$ & 98.5 & 100 \\
6 & Ethrel soaking 1 day in $0.4 \mathrm{ml} / \mathrm{l}$ & 99 & 99.5 \\
7 & Water soaking $5 \mathrm{~h}$ plus 2 days drying at $20^{\circ} \mathrm{C}$ & 85 & 91.5 \\
8 & Water soaking $12 \mathrm{~h}$ plus 2 days drying at $20^{\circ} \mathrm{C}$ & 79.5 & 85 \\
9 & Water soaking $24 \mathrm{~h}$ plus 7 days drying at $20^{\circ} \mathrm{C}$ & 84.5 & 84.5 \\
10 & Water soaking $34 \mathrm{~h}$ plus 7 days drying at $20^{\circ} \mathrm{C}$ & 74.5 & 80.5 \\
11 & Acetone $25 \%$ for 15 min & 89.5 & 92.5 \\
12 & Potassium nitrate $(0.2 \%)$ for 10 min & 83 & 88 \\
\hline
\end{tabular}

Table 3: Analysis of variance for seeds germinated on the $4^{\text {th }}$ and $7^{\text {th }}$ day using 12 different treatments

\begin{tabular}{lccccc}
\hline \multirow{2}{*}{ Variable } & \multirow{2}{*}{ DF } & \multicolumn{4}{c}{ F-Value } \\
\cline { 3 - 6 } & & Seeds germinated by the $4^{\text {th }}$ day & Seeds germinated by the $7^{\text {th }}$ day \\
\hline Replication & 3 & 1.15 & NS & $9 *$ & Significant \\
Treatment & 11 & & & & \\
Error & 33 & & & \\
CV & & 10 & 5 & \\
\hline
\end{tabular}

NS = non-significant; * signifiant $p<0.05 ; C V=$ coefficient of variation

Evaluation of 11 treatments seven days after treatment showed that the following were the most effective in breaking dormancy: 1) Ethrel soak for 1 day in 0.3 $\mathrm{ml} / \mathrm{l}$ (100\% germination); 2) Ethrel soak for 1 day in $0.4 \mathrm{ml} / 1$ (99\%); 3) boiling water at $100^{\circ} \mathrm{C}$ for $15 \mathrm{~min}$; (91\%); 4); water soak for $5 \mathrm{~h}$ plus 2 day drying at room temperature (91\%); 5) acetone $25 \%$ (93\%), and 6) potassium nitrate $0.2 \mathrm{~g} / \mathrm{l}(88 \%)$.

In conclusions, very little progress has been achieved by researches in breaking seed dormancy in sunflower. Seeds soaked in Ethrel $(0.3 \mathrm{ml} / 1$ or $0.4 \mathrm{ml} / \mathrm{l})$ showed excellent results, but the cost of the reagent is high and beyond the reach of poor farmers. However, the treatments with hot water at $80^{\circ} \mathrm{C}$ for $15 \mathrm{~h}$, or water soaking for $5 \mathrm{~h}$ and $12 \mathrm{~h}$ produced satisfactory results which can be easily handled and which are sufficiently inexpensive to be used by poor farmers. These two techniques can be easily used in commercial planting for the production of sunflower seeds. 


\section{Experiment 2}

In experiment 1 , it was clear that some treatments such as soaking seeds in heated water for periods of times, acetone, and potassium nitrate increased germination percentage, but this needed to be tested further using several different genotypes. In experiment 2, 12 genotypes irrespective of age groups (days to $50 \%$ flowering) were further tested.

An analysis of variance of the seeds germinated after 7 days from 12 sunflower genotypes using three treatments is shown in Table 4 . The analysis of variance indicated that there existed highly significant differences $(\mathrm{p}<0.01)$ in the number of germinated seeds among genotypes both in the acetone treatment and $24 \mathrm{~h}$ water priming, but no significant differences were observed in the control and in $\mathrm{KNO}_{3}$ (Table 4).

Table 4: Analysis of variance for seed germination after seven days for 12 genotypes using four treatments

\begin{tabular}{lccccc}
\hline \multirow{2}{*}{ Variable } & DF & \multicolumn{5}{c}{ F-Value } \\
\cline { 3 - 6 } & & Control & $25 \%$ Acetone & $\mathrm{KNO}_{3}$ & Priming $(24 \mathrm{~h})$ \\
\hline Genotype & 11 & $1.54 \mathrm{NS}$ & $3.66^{\star *}$ & $1.35 \mathrm{NS}$ & $4.40^{\star *}$ \\
Replication & 3 & & & & \\
Error & 33 & & & 30 & 19 \\
CV & & 31 & 25 & 30
\end{tabular}

$\mathrm{NS}=$ non-significant; ${ }^{\star \star}$ significant $\mathrm{p}<0.01 ; \mathrm{CV}=$ coefficient of variation

The analysis of genotypic correlations indicated that germination count in the control showed highly significant positive correlation with germination count in the acetone treatment $\left(\mathrm{r}=0.96^{* *}\right)$, treatment with $\mathrm{KNO}_{3}\left(\mathrm{r}=0.87^{* *}\right)$ and also with the $24 \mathrm{~h}$ water priming treatment $\left(\mathrm{r}=0.87^{* *}\right)$. Similarly, the analysis of phenotypic correlations indicated that germination count in the control showed good correlation but at lower significance levels with the acetone treatment $(\mathrm{r}=0.79 *), \mathrm{KNO}_{3}$ $(\mathrm{r}=0.64)$ and with $24 \mathrm{~h}$ priming $\left(\mathrm{r}=0.72^{*}\right)$.

Responses of the 12 sunflower genotypes to the control, acetone, $\mathrm{KNO}_{3}$, and 24 $\mathrm{h}$ water priming are shown in Table 5. It was observed that three genotypes, VBSG230012, VBSG-230064 and VBSG-210002, showed higher germination percentage in all the treatments compared with the control. It is also observed that $24 \mathrm{~h}$ priming with water generally produced higher germination compared with the control, although genotypic variability in response to priming was observed.

Table 5 indicated that regardless of germination technique the genotypes showed a consistently dormant reaction across all the treatments. The genotypes which are similar in the number of days to $50 \%$ flowering have a wide variation in germination percentage. Genotypes VBSG-230021, VBSG-230064 and VBSG230065 had similar germination percentages ( $71 \%$ for soaking $24 \mathrm{~h}$ ), but were different in days to $50 \%$ flowering, varying from 59 to 73 days. Similarly, the genotypes which were late in maturity (66 to 73 days to $50 \%$ flowering), such as VBSG- 
210021 and VBSG-210022 (obtained from 2 sources), showed variations in germination percentage from 17 to $71 \%$. On the other hand, some early genotypes such as VBSG-230057 (59 days), VBSG-230012 (60 days), VBSG-210002 source 2, (58 days) and VBSG-230029 (56 days) showed large variations in germination percent, $80,86,61$, and $29 \%$, respectively. These facts indicate that the dormancy is highly genotype dependent. There was no correlation between days to $50 \%$ flowering and dormancy.

Table 5: Germination response of 12 sunflower genotypes to water soaking, acetone, and $\mathrm{KNO}_{3}$ treatments

\begin{tabular}{|c|c|c|c|c|c|c|}
\hline \multirow{2}{*}{ No. } & \multirow{2}{*}{ Genotype } & \multirow{2}{*}{$\begin{array}{l}\text { Days to } 50 \% \\
\text { flowering }\end{array}$} & $\begin{array}{l}\text { Control, } 7 \text { days } \\
\text { in distilled water }\end{array}$ & $\begin{array}{l}\text { Acetone } \\
\text { treatment }\end{array}$ & $\begin{array}{l}\mathrm{KNO}_{3} \\
0.2 \%\end{array}$ & $\begin{array}{c}\text { Water soak } \\
(24 \mathrm{~h})\end{array}$ \\
\hline & & & \multicolumn{4}{|c|}{ Germination \% } \\
\hline 1 & VBSG - 210019 & 62 & 34 & 32 & 22 & 45 \\
\hline 2 & VBSG - 230057 & $\star \star 59$ & 61 & 56 & 70 & $80^{* *}$ \\
\hline 3 & VBSG - 210022 & 68 & 27 & 11 & 26 & 20 \\
\hline 4 & VBSG - 230077 & 60 & 8 & 10 & 30 & 16 \\
\hline 5 & VBSG - 230044 & 59 & 6 & 12 & 10 & 15 \\
\hline 6 & VBSG - 230021 & $\star * 73$ & 66 & 47 & 71 & 71 \\
\hline 7 & VBSG - 230012 & 60 & 72 & 85 & 82 & 86 \\
\hline 8 & VBSG - 210022 & 68 & 33 & 27 & 26 & 17 \\
\hline 9 & VBSG - 230064 & $\star \star 59$ & 47 & 71 & 71 & 71 \\
\hline 10 & VBSG - 230065 & 62 & 28 & 23 & 72 & 71 \\
\hline 11 & VBSG - 210002 & 58 & 37 & 41 & 52 & 61 \\
\hline 12 & VBSG - 230029 & 56 & 21 & 6 & 24 & 29 \\
\hline
\end{tabular}

In the context of the literature reviewed, it can be stated with confidence that the presence of dormancy in sunflower seeds causes great difficulties for rapid turnaround of sunflower seed for planting. The seed producers/breeders have to wait for more than 30 days to plant the seeds which have reached their optimum germination capacity. Several factors are involved in dormancy such as the accumulation of ABA in seed at maturity (LePage-Degivry and Garello, 1992) and pericarp and seed coat thickness (Corbineau et al., 1990).

In the present study, acetone and potassium nitrate were used to break seed dormancy. Our findings are supported by those of other authors who used organic compounds such as acetone, chloroform, ethanol and many other compounds having lipophilic properties to break seed dormancy (Adkins et al., 1984; Cohn et al., 1989; Corbineau et al., 1992). Singh and Rao (1993) used $\mathrm{KNO}_{3}$ to break seed dormancy in sunflower with reasonable success.

Several researches have undertaken research to stimulate or break dormancy in sunflower. Several growth regulators to stimulate germination are commercially used to induce germination of sunflower seeds including ethylene and ethylene precursors (Corbineau et al., 1990; 2003), ethepon (Kumari and Singh, 2000), and $\mathrm{GA}_{3}$ (Seiler, 1994; 1998 in wild sunflower species). The use of growth regulators usually requires special knowledge and handling, which is beyond the capacity of most farmers in developing areas and which are too expensive to buy. In view of 
these restraints, the technique developed in this study using $24 \mathrm{~h}$ water soak priming is very simple, easy and inexpensive and is capable of distinguishing genotypic variability for dormancy as reported by Subrahmanyam et al., 2002. However, the hours of the priming period for breaking dormancy should be confirmed with another set of sunflower genotypes (a study in progress).

\section{ACKNOWLEDGEMENT}

The authors thank Dr. P. P. Banerjee for his advice in statistical analysis and Mr. K. Hari Prasad for his efficient technical help and data handling.

\section{REFERENCES}

Adkins, S.W., Naylor, J.M., and Simpson, G.M., 1984. The physiological basis of seed dormancy in Avena fatua. V. Action of ethanol and other organic compounds. Physiol. Plant 62: 18-24.

Ahmad, S., Cheema, N.M., Khan, I.A., and Rana, M.A., 2002. Effect of age of developing kernel on germination and dormancy in sunflower. Pakistan J. Agric. Res. 17: 67-70.

Akinola, J.O., Larbi, A., Farinu, G.O., and Odunsi, A.A., 2000. Seed treatment methods and duration effects on germination of wild sunflower. Exp. Agric. 36: 63-69.

Amen, R.D., 1968. A model of seed dormancy. Bot. Rev. 34: 1-31.

Borghetti, F., Noda, F.N., and de Sa, C.M., 2002. Possible involvement of proteasome activity in ethylene-induced germination of dormant sunflower embryos. Brazilian J. Plant Physiol. 14: 125-131.

Cohn, M.A., Jones, K.L., Chiles, L.A. and Church, D.F., 1989. Seed dormancy in red rice. VII. Structure-activity studies of germination stimulants. Plant Physiol. 87: 879-882.

Corbineau, F., Gouble, B., Lecat, S., and Cóme, D., 1991. Stimulation of germination of dormant oat (Avena sativa L.) seeds by ethanol and other alcohol. Seed Sci. Res. 1: 21-28.

Corbineau, F., Bagniol, S., and Cóme, D., 1990. Sunflower (Helianthus annuus L.) seed dormancy and its regulation by ethylene. Isr. J. Bot. 39: 313-325.

Corbineau, F., and Cóme, D., 2003. Germination of sunflower seeds as related to ethylene synthesis and sensitivity. An overview. NATO Science Series sub-series I. Life and Behavioral Sciences 349: 216-221.

Connor, D.J., and Hall, A.J., 1997. Sunflower physiology. In: A.A. Schneiter (eds.) Sunflower Technology and Production. Agron. Monogr. ASA, CSSA, SSA, Madison, WI. 35: 113-182.

Holec, J., Soukup, J., and Kohout, V., 2002. Secondary dormancy in sunflower and its variation between cultivars. $12^{\text {th }}$ Symposium of the European Weed Research Society, pp. 362-363.

Kumari, C.A., and Singh, B.G., 2000. Ethephon adequacy in release of innate dormancy in sunflower. Indian J. Plant Physiol. 5: 277-280.

Le Page-Degivry, M.T., Barthe, Bianco, J. and Garello, G., 1992. Involvement of absisic acid in hormonal regulation of sunflower embryo dormancy. In: D. Cóme, and F. Corbineau (eds.). Proc. $4^{\text {th }}$ Int. Workshop Seeds, Angers, France 20-24 July, Paris pp. 615-623.

Martin, I.V., 2000. Intensive sunflower cultivation from immature seeds. Helia 23(33): 129-134.

Nerson, H., and Govers, A., 1986. Salt priming of muskmelon seeds for low temperature germination. Sci. Hortc. 28: 85-91.

Sachs, M., 1977. Priming of watermelon seeds for low-temperature germination. J. Am. Soc. Hort. Sci. 102: 175-178.

Seiler, G.J., 1993. Wild suflower species germination. Helia 16(18): 15-20.

Seiler, G.J., 1994. Dormancy and germination of wild Heliantus species. In: P.D.S. Calligan and D.J.N. Hind (eds.). Compositae: Biology Utilization. Proc. Intl. Compositae Conf. Kew, 1994, Royal Botanic Garden, Kew Vol. 2: 213-222.

Seiler, G.J., 1998. Seed maturity, storage time and temperature, and media treatment effects on germination of two wild sunflowers. Agron. J. 90: 221-226. 
Singh, H.G., and Rao, G.R., 1993. Effect of chemical soaking of sunflower (Heliantus annuus) seed on vigour index. Indian J. Agric. Sci. 63: 232-233.

Subrahmanyam, S.V.R., Kumar, S.S., and Ranganatha, A.R.G., 2002. Genotypic differences for seed dormancy in sunflower (Helianthus annuus L.). Seed Res. (New Delhi) 30: 325-327.

Taylorson, R.B., and Hendricks, S.B., 1979. Overcoming dormancy in seeds with ethanol and other anaesthetics. Planta 145: 507-510.

\title{
DESARROLLO Y ESTANDARDIZACIÓN DE LA TÉCNICA SIMPLE DE ROMPER EL LETARGO DE SEMILLA DE GIRASOL (Helianthus annuus L.)
}

\author{
RESUMEN
}

El letargo de semilla causa grandes problemas en la producción de girasol de semilla eficaz. Se han hecho intentos de crear una técnica simple para romper el letargo de la semilla. En el primer experimento, fueron calificadas diferentes técnicas mediante el tratamiento con regulador de crecimiento, Etrel, preparación (sumergido en el agua, y luego mantenerlo en la sombra durante 2-3 días), con químicos, como acetona $\left(\mathrm{CH}_{3} \mathrm{COCH}_{3}\right)$ y nitrato de potasio $\left(\mathrm{KNO}_{3}\right)$. El último de los químicos mencionados mostró los mejores resultados. Para probar estas halladas, la eficacia de varios tratamientos $(25 \%$ acetona, $0.2 \% \mathrm{KNO}_{3}$ y sumergido en el agua durante 24 horas con secado) fue calificada en 12 genotipos de girasol. El sumergido en el agua durante 24 horas, fue considerado una técnica simple que promete el rompimiento del letargo de la semilla exitoso. Son necesarias unas pruebas adicionales de los resultados obtenidos, que pueden obtenerse investigando los genotipos de girasol de diferentes grupos de maduración, tanto como investigando diferentes longitudes de períodos de sumergido de semilla en el agua.

\section{DÉVELOPPEMENT ET NORMALISATION D'UNE TECHNIQUE SIMPLE POUR ROMPRE LA DORMANCE DE LA GRAINE DE TOURNESOL (Helianthus annuus L.)}

\author{
RÉSUMÉ
}

La dormance de la graine cause un grand problème pour l'efficacité de la production germinale du tournesol. Des essais ont été faits dans le but de développer des techniques simples pour rompre la dormance de la graine. Dans la première expérience, différentes techniques ont été évaluées par l'utilisation de traitements comme un régulateur de croissance, l'Ethrel, préparation (immersion dans l'eau suivie de $2-3$ jours de séchage à l'ombre), produits chimiques comme l'acétone $\left(\mathrm{CH}_{3} \mathrm{COCH}_{3}\right)$, et le nitrate de potassium $\left(\mathrm{KNO}_{3}\right)$ qui a donné les résultats les plus prometteurs. Pour confirmer ces découvertes, plusieurs traitements $\left(25 \%\right.$ d'acétone, $0,2 \%$ de $\mathrm{KNO}_{3}$ et immersion dans l'eau pendant 24 heures suivie de séchage) ont été effectués et évalués chez 12 génotypes de tournesol. L'immersion dans l'eau au cours de 24 heures est considérée comme une technique simple et prometteuse pour l'interruption de la dormance de la graine. De nouvelles confirmations pouvant être obtenues par utilisation de génotypes de tournesol de différents groupes de maturité sont nécessaires ainsi que des analyses par différentes périodes d'immersion. 
